\title{
'All men have been considered equal by me': The attitude of Amatus Lusitanus towards treating gentiles according to his Physician's Oath
}

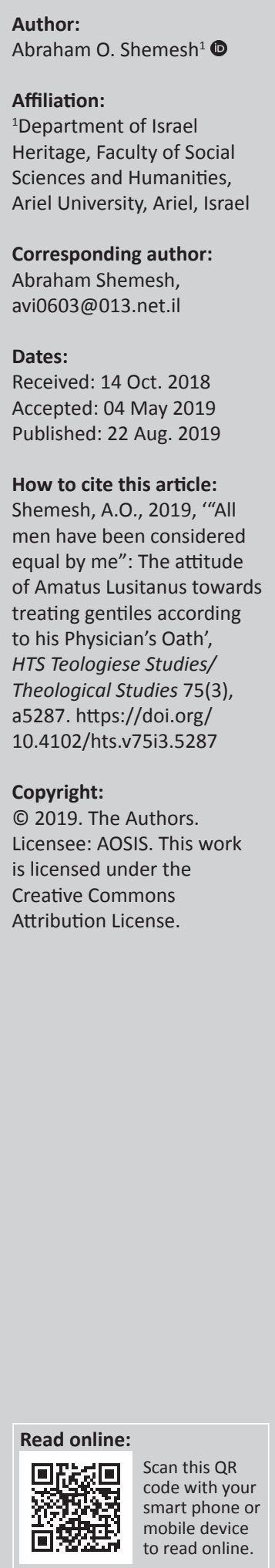

The ancient Jewish law took a strict approach to medical relationships between Jews and non-Jews. The current study deals with the attitude of Amatus Lusitanus (1511-1568), a notable Portuguese Jewish physician towards treating gentiles. The Physician's Oath of Lusitanus emphasises that as a doctor he treated people from varied faiths and socio-economic status. Lusitanus treated many non-Jews. For instance, he received an invitation from the municipality of Ragusa to serve as the town physician and he accepted this mission. In Anconare, he was called upon to treat Jacoba del Monte, sister of Pope Julius III, and he also prescribed for Julius himself. Amatus Lusitanus was forced to leave his country because of the Portuguese inquisition and wandered in many countries. Despite the hostile religious attitude of his close surroundings, he did not retaliate against his patients and provided medical treatment indiscriminately.

Keywords: Amatus Lusitanus; Jewish physician; Physician's oath; Amati Iusiurandum; Centuriæ; Asaph Harofe; Maimonides; Hippocratic oath.

\section{Introduction}

The physician's duty to provide medical treatment to patients from all backgrounds and social classes is one of the basic ethical principles of modern medicine. The origin of this concept is the Hippocratic Oath, attributed to Hippocrates (460-370 BC), one of the great Greek physicians of ancient times. According to the Hippocratic Oath, the duty of the physician is to heal human beings wherever they are, with no regard for their personal status, whether free or slaves, or their socio-economic class: 'whatever may be the rank of those who it may be my duty to cure, whether mistress or servant, bond or free' (Copland 1825:258; Edelstein 1943).

The physician-patient relationship has not only medical significance, but social significance as well, as it creates an essential point of convergence between people who belong to diverse faiths and cultures, which are sometimes rival and hostile.

\section{Purpose of the study}

The current study addresses the attitude of the Portuguese doctor Amatus Lusitanus, one of the greatest Jewish doctors in the 16th century, to providing medical service to non-Jews. Similar to other Jewish doctors, Lusitanus too treated both gentiles and Jews, despite the position of Mishnaic and Talmudic sources whereby medical services should not be provided to gentiles. The study is based on the following questions:

1. Was Amatus Lusitanus forced to treat non-Jews, as he was a crypto-Jew (see below), or whether he believed that any person in need should be treated? This question is even more acute in light of his Physician's Oath (Amati Iusiurandum), in which he declared that he had provided medical treatment to members of all faiths. This is an unusual phenomenon among ancient doctors and the reason for this declaration is worthy of exploration. I shall examine his attitude to providing medical service to non-Jews by examining different editions and versions of the oath and comparing its contents in this regard to other Jewish versions, for example, that of Asaph Harofe.

2. Amatus Lusitanus suffered from the Portuguese Inquisition, and he was forced to wander from place to place. Did his complicated biographical background influence his attitude towards treating non-Jews patients? I shall compare Lusitanus' case to another Jewish doctor who had experienced the oppression of the Inquisition and was required to treat gentiles. 


\section{Amatus Lusitanus: Biographical background}

João Rodrigues de Castelo-Branco (Figure 1), known as Amatus Lusitanus, was born in Castelo Branco, Portugal, in 1511. Lusitanus was the descendant of a Marrano family, which seems to have converted to Christianity in Portugal's forced conversion of 1497 (Friedenwald 1937).

Lusitanus studied medicine and botany at the University of Salamanca, Spain. After graduating as a medical doctor (ca. 1530) he remained in Portugal for a short period, but was forced to leave for fear of the Portuguese Inquisition. From this time on, he could not stay at any one place for a long time. In 1533, he travelled to Antwerp, where he worked as a botanist and acquired thorough knowledge of medicinal herbs and achieved a reputation as a specialist. Then he wandered through the Netherlands and France, finally settling in several Italian cities - Ferrara, Ancona and Pesaro. During his sojourn at Pesaro, he received an invitation from the free Ragusan Republic (Dubrovacka Republika, presentday Dubrovnik) in the Adriatic Sea to serve as the town doctor (Dürrigl \& Fatovic-Ferencic 2002:37-40). After staying there for a few months, he travelled to Salonica, Greece, which was his last stop. Salonica was part of the Ottoman Empire and had a large Jewish community; there he openly professed the Jewish faith and finally died in a plague in 1568 (Friedenwald 1937; Friedenwald, 1944a).

In the world of medicine, Lusitanus became known for his important and valuable works, such as Index Dioscoridis (1536); Enegemata in Duos Priores Dioscoridis de Arte Medica Libros (Antwerp, 1536); Enarrationes Eruditissimæ (Venice, 1553);

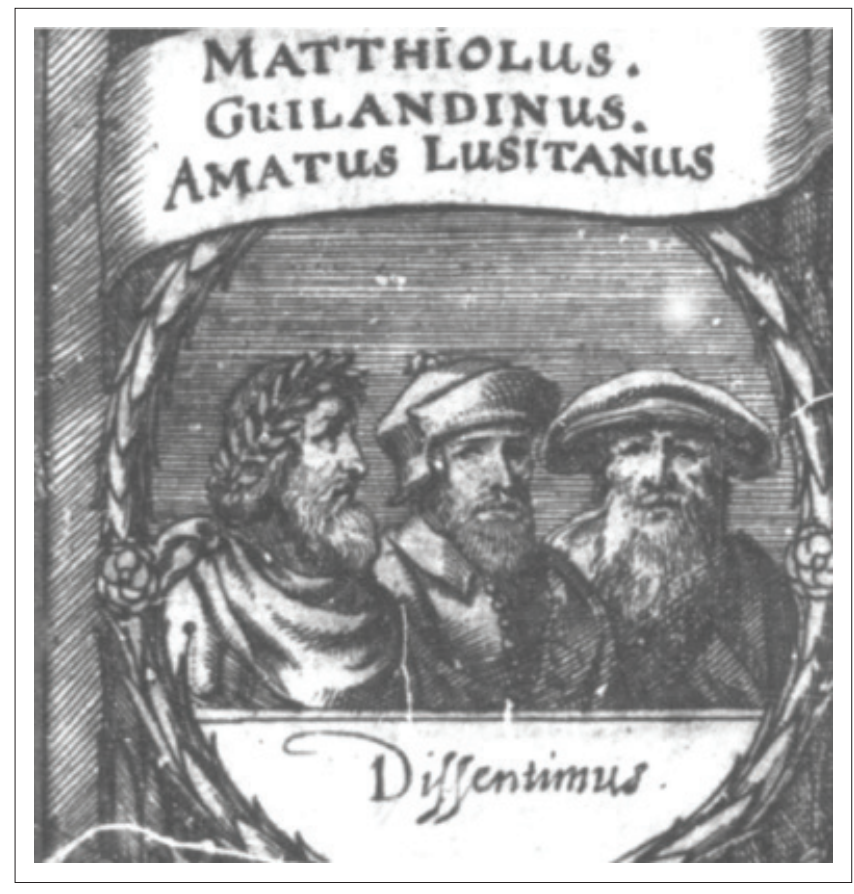

Source: Beyond Chicken soup, n.d., Harry Friedenwald: Collecting Jewish Doctors, (Librar Case 2), viewed n.d., from http://chickensoupexhibit.org/harry-friedenwald-collectingjewish-doctors/

FIGURE 1: Pietro Andrea Mattioli, Melchior Guilandinus and Amatus Lusitanus.
In Dioscorides de Medica materia Librum quinque enarrationis (1556); De Crisi et Diebus Decretoriis (Venice, 1557); In Dioscoridis Anazarbei de Medica Materia Libros Quinque (Venice, 1557) and Commentatio de Introitu Medici ad Ægrotantem (Venice, 1557). The most important work was in seven volumes - Curationum Medicinalium Centurix Septems (in short: Centurix, Florence, 1551) - in which he published accounts of his medical cases and their treatment (Deutsch and Broydé 1901-1906; Friedenwald 1955).

Lusitanus became famous not only because of his works, but also for his discovery concerning the circulatory system. Through dissections of the azygos vein, Lusitanus was the first to observe and speculate about the venous valves and their role in the body's blood flow (on the part of Lusitanus and other Sephardic converso physicians in the scientific revolution in the field of medicine, see Ruderman 1995:273-309).

As Winfried Schleiner has shown, Lusitanus also had an important contribution to the field of medical ethics (Schleiner 1994:147-59; Schleiner 1995:49-61). One of his contributions to this field is the Physician's Oath, which is brought at the end of the sixth and seventh Centurix (on the oath, see Saperstein and Marcus 2015). The oath was originally written in Latin in 1559 and it was translated into several languages. In 1917, it was translated into English by Harry Friedenwald (1864-1950), ophthalmologist and historian of Jewish medicine (Friedenwald 1917), and it was also translated into Hebrew by several scholars (Margalit 1970:151; Steinberg 1979:250).

The researcher Evangelia Varella explains the reason for publishing the oath in Salonica. He argues that the Hippocratic Oath had been interpreted from a Christian viewpoint, while the Ottomans recognised the numerous Islamic efforts to regulate the conduct of doctors. The Jewish Sephardic community added their own thoughts, some old and some new, while Western Europe adopted standards according to the specific needs of medical schools. The Physician's Oath of Lusitanus combines varied medical traditions of antiquity and of the Middle Ages, and it is a result of the special conditions that existed in Salonica, where a new scientific perspective was added to the ethical foundations of medicine (Varella 2006).

\section{The prohibition to cure non-Jews in ancient literature: de jure and de facto}

Throughout the ages, the Jewish literature points to the hostility between Jews and non-Jews in the field of medicine. The first signs of medical restrictions of Jewish-gentile relationships emerged and crystallised in the Mishnah and Talmud periods (ca. 3rd century BCE-5th century CE). The classical rabbis imposed a double restriction:

1. They prohibited the provision of medical services to non-Jews - medical care, circumcisions and delivering their babies (Mishna, Avoda Zara, 2:1; Babylonian 
Talmud, Avoda Zara, 26b). This prohibition was based on the injunction against assisting and supporting pagan societies that contradict the foundations of the monotheistic Jewish faith (Mishna, Avoda Zara, 1:1-2; 2:2; Babylonian Talmud, ibid., 25b).

2. At the same time, receiving services from non-Jewish physicians and healers was limited also for fear of harassment or murder disguised as a medical failure (Mishna, Avoda Zara, 2:2; Tosefta, Hulin, 2:21, Zuckermandel edition: 503). It was forbidden to receive medical treatment from non-Jews or to buy medicines that might be lethal if taken in inexact dosages, such as opium and theriac (Jerusalem Talmud, Avoda Zara, 2:2, 40d). Another concern was the use of idolatrous elements contradicting the patient's Jewish faith as part of the medical treatment, or the negative religious influence of non-Jewish physicians on Jewish patients (Babylonian Talmud, Avoda Zara, 27b).

These religious restrictions might have aggravated the friction between the faiths and created severe social conflicts, particularly in circumstances that entailed a mixed society utilising joint systems. As a result, as early as the Talmudic age we see rabbinical reservations with regard to the allinclusive prohibition of medical relationships. Accordingly, the risk of interfaith tension served as grounds for permitting medical treatment of non-Jews and assisting in the labour of non-Jewish women, for a fee (Babylonian Talmud, Avoda Zara, 26b).

Notably, in the Middle Ages and in early modern times, nonJewish society prevented Jews from fully participating in the medical profession. In medieval Christian Europe, Jews were forbidden from treating Christians. The law prohibiting Jewish medical treatment of Christians was enacted by Pope Eugene IV in 1431. It was approved by Nicholas V in 1447 and taken to an extreme by Paul IV in 1555 (Carpi 1989:67; Hendel 1956; Shapira 1960:110). In the same way, Jews encountered obstacles in admissions to medical studies, as the universities in Europe were, to a great degree, religious institutions intended for members of their faith. These institutions posed difficulties, charged double rates and maintained teaching schedules that were inconvenient for observant Jews. Nevertheless, some Jewish doctors attained a high professional level, became well known and received positions in the courts of popes and secular sovereigns (Hendel 1956).

\section{Was Lusitanus different than other Jewish doctors with regard to the treatment of gentiles?}

Over the course of his lifetime Lusitanus attended to members of the higher classes, and according to his oath he also treated common people. In the same way, he treated Jews as well as non-Jews. In 1533, when he moved to Antwerp, Belgium, he treated Gracia Mendes Nasi (1510-1569), one of the wealthiest Jewish women of Renaissance Europe, the Portuguese consul and the mayor. During his stay in Ferrara (1546-1552), Amatus Lusitanus received an invitation from the King of Poland to move to that country, which he declined, preferring to settle in Ancona where religious tolerance existed. Here he was called upon to treat Jacoba del Monte, sister of Pope Julius III, and he also prescribed for Julius himself (on curing Azariah dei Rossi at this time, see Friedenwald 1944b). During his sojourn at Pesaro, he received an invitation from the municipality of Ragusa to serve as the town physician and he accepted this mission (Dürrigl \& Fatovic-Ferencic 2002).

Historical accounts indicate that Lusitanus was not exceptional in treating gentiles. Quite a few Jewish doctors served as court physicians of non-Jewish kings and rulers. These doctors treated the rulers themselves, their family members and the royal officialdom, and even met with much acclaim. One conspicuous example is Maimonides (1138-1204), who was one of the 21 court physicians of the Ayubi vazir al-Fadil and even notes in one of his letters the appeals of the general public for medical care (Shilat 1987-1978, II:550-552). In his halakhic compositions, Maimonides expressed a strict approach forbidding the treatment of gentiles, although in practice he himself did so (see, e.g., Maimonides, Mishne Torah, Frankel 2002 edn., Hilchot Avoda Zara, 10:2). This contradiction was raised by sages in subsequent generations and various explanations were proposed. Some claimed that the prohibition related only to idolaters, while the Muslims believe in one God and treating them is permissible (Benveniste 1987:187; Benveniste 1997:18-19; Benveniste 2008:129-130). Others claimed that treating for a fee is permissible and that is what the Rambam did. Refusal or avoidance of treating the king is of course risky and this concern as well may have been taken into account (Moses Mikkotsi 2003:81).

In the Physician's Prayer, which first appeared in German in 1738 , there is a section in which the physician expresses an obligation to treat any person (Friedenwald 1917). Suessmann Muntner (1942:121) argued that this prayer was attributed to the Rambam; however, as shown by Joshua Leibowitz, the prayer was composed by Jewish-German physician Marcus Herz (1747-1803), a member of the Enlightenment movement in Berlin (Leibowitz 1954; Rosner 1967:440-454). Indeed, in light of the Rambam's halakhic reservations with regard to oaths (Mishne Torah, Hilkhot Shvu'ot 12:12) and his hostile attitude to treating gentiles, it is hard to assume that he composed the prayer.

Maimonides was not the only one to treat gentiles, but there were many other doctors who were known to have done so. It may be assumed that subsequent doctors saw in his conduct a model or precedent.

\section{Lusitanus' attitude to treating gentiles according to his Physician's Oath}

Lusitanus' oath was written in Salonica in 1559, 9 years before his death, when he had already professed himself 
Jewish. Analysis of the oath and its comparison to the medical oath composed by Asaph the physician (Asaph Harofe), also known as Asaph ludeus or Asaph Hayeudi (Middle East 6th7 th or 10th century AD), that his book (Book of Asaph or Book of Medicine) is the oldest known medical Hebrew manuscript, raises several unique points regarding the oaths:

1. In the oath of Asaph Harofe, he forms a pact with his students and administers to them an oath whereby they will treat their patients with devotion, based on Jewish and universal humane criteria: 'This is the pact which Asaph ben Berakhyahu and Yohanan ben Zabda made with their pupils, and they adjured them with the following words' (the quotations are according to Pines 1975:224-226. See also Rosner \& Muntner 1965; Muntner 1968). Lusitanus' oath, in contrast, is personal. He speaks in the single form and administers the oath to himself alone - 'I swear by eternal God' (Friedenwald 1917).

2. Asaph's oath is worded in the future form: 'Do not make a woman [who is] pregnant as a result of [whoring] take a drink with a view to causing abortion/Do not covet beauty of form in women with a view to fornicating with them (Pines 1975:224-226), while Lusitanus' is worded in the past form, for instance, 'I have revealed to no one a secret entrusted to me/I have given to no one a fatal drought/No woman has brought about an abortion by my aid' (Friedenwald 1917). Asaph's oath is a future commitment by students who completed their medical studies to adhere to moral medical behaviour during their occupation as doctors. Lusitanus, in contrast, wrote his oath at the end of his life and it relates to his unblemished medical activity in the decades since he began working as a doctor.

3. While Asaph does not relate to treating gentiles or members of other cultures, Lusitanus' oath includes a section that refers to this: 'All men have been considered equal by me, of whatever religion they were, whether Hebrews, Christians or the followers of the Moslem faith (Friedenwald 1917).

In an article published by the Israeli paediatric neurologist, medical ethicist and writer of Encyclopedia of Jewish Medical Ethics, Rabbi Prof. Abraham Steinberg, under the title 'Prayers and oaths of patients and doctors' he brings the text of Lusitanus' oath, but the section mentioned appears in parentheses (Harry Friedenwald [1917] presents this section without parentheses), and the author notes this is 'a later addition, and it may have been occasioned by the censor' (Steinberg 1979:248-256). Interestingly, in his medical halakhic encyclopedia he brings the section in a slightly different form, without parenthesis and with no comments (Steinberg 1998, VI:153).

Examination of the oath (Amati Iusiurandum), which appears at the end of the sixth Centurix in the original Latin version from Anno mundi 5319 (= year 1559), shows that the section mentioning treating people of different faiths is an inseparable part of the oath:

Eodemq; loco femper apud me fuiffe cuiusuis religionis homines fiue ij Hebraei, fiue Christiani, aut Arabicae legis fectatores effent. (Amati Lusitani 1559:381-382; see Figure 2)

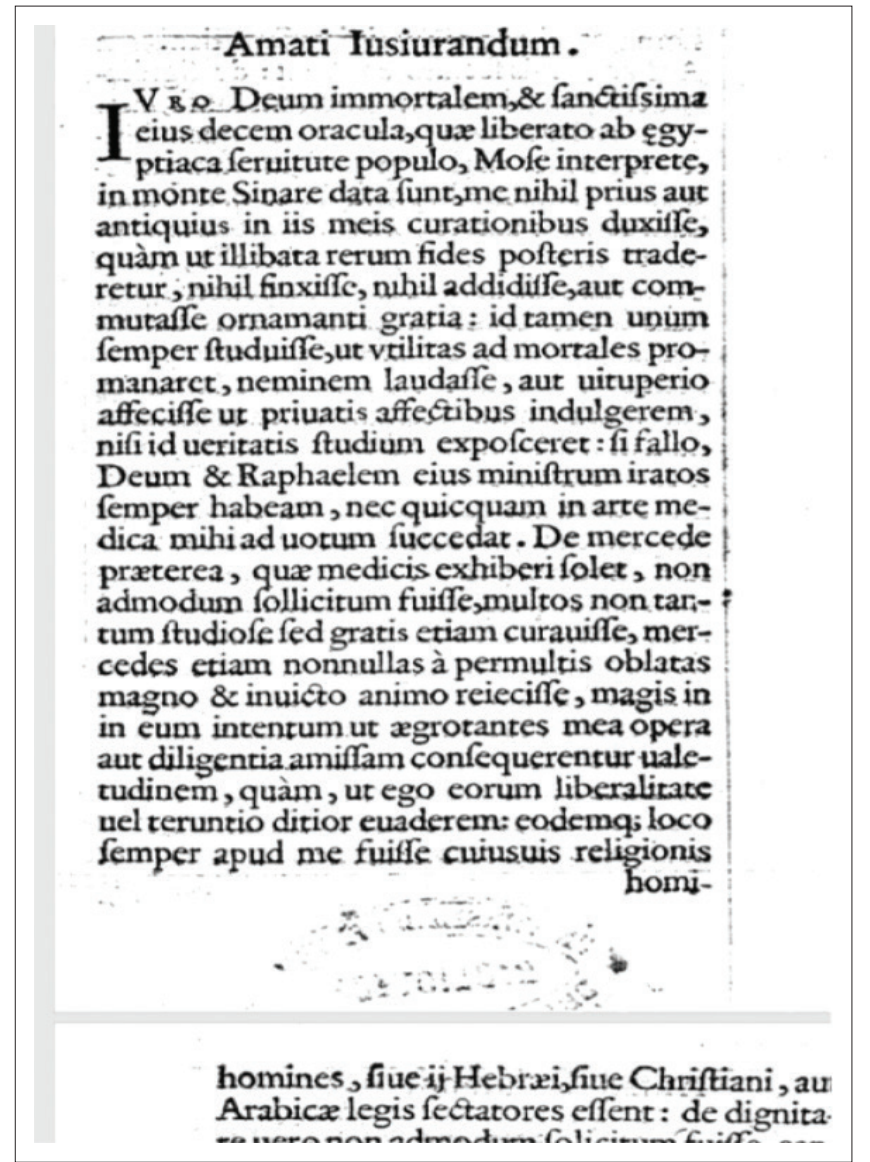

Source: Lusitani Amati, 1559, Curationum medicinalium Amati Lusitani medici physici praestantissimi centuriae duae, quinta videlicet ac sexta, viewed 01 March 2019, from https://books.google.co.il/books?id=P8HSuAuodugC\&pg=PT205\&lpg=PT205\&dq=Amati+Lu sitani+curationum+medicinalium+centuriae +Vi\&source=bl\&ots=JPIZK9TaT-\&sig= UrtjQMGtIrbrlBF4ROctip_U\&f4\&hl=iw\&sa=X\&ved=0ahUKEwiRhZv0obrbAhUQbVAKHTzPD\& AQ6AEIRjAL\#v=onepage\& $q=A m a t i \% 20$ Lusitani\%20curationum\%20medicinalium $\% 20$ centuriae\%20Vi\&f=false.

FIGURE 2: Amati lusiurandum, Curationum medicinalium Amati Lusitani medici physici praestantissimi centuriae duae, quinta videlicet ac sexta (Lusitani 1559:381-382).

The suggestion that this is an addition by the censor is unfounded and raises several difficulties:

1. The oath was written in Salonica, which was under Ottoman rule. The assumption that the words of the oath had been censured is irrelevant, as censorship was only customary in Christian Europe.

2. It is not clear why the censor found it important to add this section. As stated above, the customary policy among the church was to prohibit Jews from treating Christians (aside from exceptional cases), and thus such a declaration is not compatible with the conduct of the church.

Assuming that the declaration was written by Lusitanus, it seems that he did not see this as a post-factum practice but rather was proud of having treated gentiles. Notably, this is not a simple declaration from a halakhic point of view, as the basic license to treat gentiles did not solve other problems deriving from the encounter between Jewish doctors and patients from another faith. Providing medical services to gentile patients generated problems in various halakhic areas, for instance, medical acts on the Sabbath that involve performing practices forbidden according to Jewish law. 
In contrast to the oaths of Hippocrates and of Asaph Harofe, which do not use a negative form of speech, Lusitanus speaks of his devoted care of his patients over the years and mentions a personal experience whose association with medical ethics is worthy of attention. He writes:

In my method of studying I have been so from the reading of good authors, nor the eager that no task, however difficult, could lead me away loss of private fortune, nor frequent journeys, nor Yet exile, which, as befits a philosopher, I have thus far borne with calm and invincible courage. (Friedenwald 1917)

As stated by Gutwirth, the distancing and estrangement experienced by Lusitanus during his wanderings are a constant element in all his books and have an impact on the treatment he offered his patients, particularly the mental care. Gutwirth writes:

Amatus Lusitanus' concern with exile, his attention to - and views on - individuals who, like himself, are far from their lands, perhaps particularly from the Iberian Peninsula, may be found throughout his work. (Gutwirth 2009:58)

The personal experience that Lusitanus refers to in his oath emphasises that he continued to treat his patients devotedly despite his personal tribulations, particularly as a Jew fleeing the Portuguese Inquisition. I understand this section as corresponding with the previous one, where he declares the obligation to treat any person devoid of the religious discrimination from which he himself suffered. Namely, despite being a crypto-Jew he did not use his trying personal experiences to justify harm to others. Personal distress deriving from religious discrimination might lead to frustration and guilt feelings, but Lusitanus behaved to the contrary. His personal suffering occasioned by the alienated gentile surroundings stimulated him to help those who were suffering.

\section{Discussion}

Analysis of Lusitanus' personal biography and the oath where he declares that he treated members of all faiths and cultures equally forms the impression that Lusitanus was not only a qualified medical practitioner rather also a man of morals and conscience who perceived his medical work as an obligating moral challenge. As stated, his suffering and his wanderings did not affect his true conscience, and he continued to treat patients from among the same groups that had wronged him.

The question is how did other Jewish doctors act in similar situations? Is it possible to compare Lusitanus' attitude to gentile patients to that of Jewish doctors who had experienced the oppression of the Inquisition and were required to treat gentiles? In the following lines I shall depict an opposite case, one of a Jewish doctor who came from a crypto-Jewish family and deliberated on whether it is permissible to harm gentiles in his medical practice, apparently because of a desire for revenge.

In a response to a question sent by Dr Abraham Baruch Harofe to Rabbi Chaim Benveniste in 1665, he inquired whether Jewish physicians attending gentiles are permitted to kill them by administering poisonous drugs or to cause their death indirectly by withholding medical treatment:

Query: May our Rabbi teach us whether doctors who treat Gentiles, Ishmaelites [Muslims], Arelim [uncircumcised, Christians], and Amalekites [the meaning of 'Amalekites' in this case is not clear] are permitted to give them terufot negdiyot [counter-medicines; medical compounds containing toxins that were used to cure snake bites and the like but could also cause death] so that they die, or at least to withhold treatment so that they die, or is all of this prohibited. (Benveniste 1791:129b)

This seemingly general question by Abraham Baruch raises the real possibility of a doctor misusing his medical authority to harm innocent people under the guise of failed medical treatment. The concept of non-maleficence (in Latin: Primum non nocere) is one of the basic ethical principles (on this principle, see Smith 2005:371-377). The questions that arise are the following: who was this doctor, Abraham Baruch, what were the circumstances of his question, and does it imply a real intention to harm gentiles?

Gershom Scholem surmised that Abraham Baruch was a well-known doctor from Izmir who was a follower of Shabbetai Zvi. This is apparently the same man mentioned by the name Dr Barut in a book by the Dutch priest Thomas Künen, published in 1669, described as a doctor whose medical services were used by many Christians. Abraham Baruch, appointed by Shabbetai Zvi as 'King of Portugal', was descended from Portuguese crypto-Jews, and some of his family continued to live as crypto-Jews in France (Scholem 1957:111-112, 351; on Shabbetaic doctors, see Barnai 1984, II:291-292). Assuming that this is the same person, David Tamar proposed that his hatred for gentiles in general, and for Christians in particular, was caused by his own life experience and by his messianic zeal. It is not surprising that such a man, who believed that the Messiah had arrived and would redeem Israel and avenge its enemies, wished to be an active part of that process (Tamar 1981:143-144).

In his lengthy answer, Rabbi Chaim Benveniste quoted multiple sources from talmudic and rabbinical literature that deal with the different situations in which it is permitted or forbidden to cause the death of gentiles, such as when they are not at war with Jews or when Jews are in a weakened position. He argues that if the gentile is a person who does harm to Jews, it is permitted to harm him, even directly, in the guise of medical treatment. On the contrary, if the gentile is not one who harms Jews, there is no obligation to harm him and it is better not to do so, even indirectly.

It is not clear whether this is a theoretical or practical question. Even if we assume that it is a practical question, it is clear that inflicting harm on innocent victims was a limited practice, as harming many patients would have given away the vengeful doctor. Moreover, it seems that Abraham Baruch's malicious intentions of harming gentiles through medical treatment are an exception and that they stemmed from messianic motives, and therefore it is not possible to conclude from this about a more extensive phenomenon among Jewish doctors. In any 
case, it is clear that the concern of the minority population that they would be harmed by the rulers was not one-sided, rather the oppressed also desired to harm those whom they perceived as the source of their suffering.

\section{Conclusion}

The Physician's oath of Lusitanus emphasises that as a doctor he treated people from varied faiths and socio-economic status. In spite of the hostile religious attitude of his close surroundings, he did not retaliate against his non-Jewish Christian and Muslim patients and provided medical treatment indiscriminately.

\section{Acknowledgement Competing interest}

The author declares that he has no competing interest exists.

\section{Author contributions}

I declare that I am the sole author of this research article.

\section{Ethical consideration}

This article followed all ethical standards for carrying out research without direct contact with human or animal subjects.

\section{Funding}

This research received no specific grant from any funding agency in the public, commercial, or not-for-profit sectors.

\section{Data availability statement}

Data sharing is not applicable to this article as no new data were created or analysed in this study.

\section{Disclaimer}

The views and opinions expressed in this article are those of the authors and do not necessarily reflect the official policy or position of any affiliated agency of the authors.

\section{References}

Barnai, Y., 1984, 'The Marranos of Portugal in Izmir in the Seventeenth Century', in S. Etinger (ed.), Nation and its history, vol. II, pp. 291-292, Merkaz Shazar, Jerusalem [Heb].

Benveniste, C., 1791, Responsa Baye Haye, Yoreh De'ah, Chaim Baruch Saporta Press, Salonica.

Benveniste, C., 1987, Knesset Hagedolah, Orcah Chaim, Mechon Ha-Ktav, Jerusalem.

Benveniste, C., 1997, Dina Dehaya, Mechon Ha-Ktav, Jerusalem.

Benveniste, C., 2008, Shyarei Knesset Hagedolah, Yoreh De'ah, Mechon Ha-Ktav, Jerusalem.

Beyond Chicken soup, n.d., Harry Friedenwald: Collecting Jewish Doctors, (Library Case 2), viewed n.d., from http://chickensoupexhibit.org/harry-friedenwaldcollecting-jewish-doctors/

Carpi, D., 1989, Between renaissance and Ghetto: Essays on the history of the Jews in Italy in the 14th and 17th centuries, University Publishing Project, Tel Aviv [Heb].
Copland, J., 1825, 'The Hippocratic Oath', The London Medical Repository 23(135), 258.

Deutsch, G. \& Broydé, I., 1901-1906, 'Juan Rodrigo de Castel-Branco', in I. Singer et al. (eds.), Jewish Encyclopedia, vol. 7, pp. 299-300, Funk \& Wagnalls Company, New York.

Dürrigl, M.A. \& Fatovic-Ferencic, S., 2002, 'The medical practice of Amatus Lusitanus in Dubrovnik (1556-1558), A short reminder on the 445th anniversary of his arrival', Acta Medica Portuguesa 15(1), 37-40.

Edelstein, L., 1943, The Hippocratic Oath: Text, translation and interpretation, Johns Hopkins Press, Baltimore, MD.

Frankel, S., 2002, Mishneh Torah, Hotza'at Shabse Frankel Ltd, Jerusalem and Benei-Brak.

Friedenwald, H., 1917, 'The ethics of the practice of medicine from the Jewish point of view', Johns Hopkins Hospital Bulletin 28(318), 256-266, viewed 28 July 2019, from http://ijme.in/wp-content/uploads/2016/11/282-5.pdf.

Friedenwald, H., 1937, 'Amatus Lusitanus', Bulletin of the Institute of the History of Medicine, The Johns Hopkins University 5(7), 603-653.

Friedenwald, H., 1944a, 'Amatus Lusitanus: Essay XXV', in H. Friedenwald (ed.), The Jews and medicine: Essays, pp. 332-380, The Johns Hopkins Press, Baltimore (Reprint Ktav Publishing House, New York 1967).

Friedenwald, H., 1944b, 'Two Jewish physicians of the sixteenth century. The Doctor, Amatus Lusitanus, the Patient, Azariah dei Rossi', in H. Friedenwald (ed.), The Jews and medicine: Essays, pp. 391-403, Johns Hopkins University Press, Baltimore, MD.

Friedenwald, H., 1955, 'Medical works of Amatus Lusitanus', in J.L. Dias (ed.), Homenagem ao Doutor João Rodrigues de Castelo Branco, pp. 180-181, Câmara Municipal, Castelo Branco.

Gutwirth, E., 2009, 'Jewish bodies and renaissance melancholy: Culture and the city in Italy and the Ottoman Empire', in G. Veltri (ed.), The Jewish Body: Corporeality, society, and identity in the renaissance and early modern period, Maria Diemling, pp. 57-92, Brill, Leiden.

Hendel, M., 1956, The Jewish Doctor in the 17th-18th centuries, Y. Chechick, Tel Aviv.

Leibowitz, J., 1954, 'The doctor prayer attributed to Maimonides', Dapim Refu'im 13(1), 77-81.

Lusitani Amati, 1559, Curationum medicinalium Amati Lusitani medici physici praestantissimi centuriae duae, quinta videlicet ac sexta, viewed 01 March 2019 praestantissimi centuriae duae, quinta videlicet ac sexta, viewed 01 March 2019,
from https://books.google.co.il/books? id=P8HSuAuodugC\&pg=PT205\&/pg=PT20 from https://books.google.co.il/books?id=P8HSuAuodugC\&pg=PT205\&lpg=PT20 5\&dq=Amati+Lusitani+curationum+medicinalium+centuriae+Vi\&source=bl\&ots=
JPIZK9TaT-\&sig=UrtjQMGtIrbrlBF4ROctip_U8f4\&hl=iw\&sa=X\&ved=0ahUKEwiRhZ JPIZK9TaT-\&sig=UrtjQMGtIrbrlBF4ROctip_U8f4\&hl=iw\&sa=X\&ved=0ahUKEwiRhZ
v0obrbAhUQbVAKHTzPD8AQ6AEIRjAL\#v=onepage\&q=Amati $\% 20$ Lusitani $\% 20$ voobrbAhUQbVAKHTZPD8AQ6AEIRjAL\#v=onepage \&q=Am
curationum $\% 20$ medicinalium $\% 20$ centuriae $\% 20$ Vi\&f=false.

Margalit, D., 1970, The way of Israel in medicine, The Academy of Medicine, Jerusalem.

Moses Mikkotsi, 2003, Sefer Mitzvot Gadol, Mechon Jerusalem and Mechon Shlomo Uman, Jerusalem.

Muntner, S., 1942, 'A Prayer of Moses', Sinai 12, 120-132.

Muntner, S., 1968, 'Hebrew medical ethics and the oath of Asaph', The Journal of the American Medical Association 205(13), 912-913. https://doi.org/10.1001/ jama.1968.03140390036009

Pines, S., 1975, 'The oath of Asaph the physician and Yohanan Ben Zabda, its relation to the Hippocratic oath and the Doctrina DuarumC Viarum of the Didache', to the Hippocratic oath and the Doctrina DuarumC Viarum of the Didache',
Proceedings of the Israel Academy of Sciences and Humanitis 9, 223-264, viewed Proceedings of the Israel Academy of Sciences and Humanitis 9, 223-264, viewed
25 February 2019, from https://web.archive.org/web/20160304042841/http:// www1.umn.edu/phrm/oaths/oath5.html.

Rosner, F., 1967, 'The physician's prayer attributed to Maimonides', Bulletin of the History of Medicine 41(5), 440-454.

Rosner, F. \& Muntner, S., 1965, 'The oath of Asaph', Annals of Internal Medicine 63(2), 317-320. https://doi.org/10.7326/0003-4819-63-2-317

Ruderman, D.B., 1995, Thought and scientific discovery in early modern Europe, Yale University Press, New Haven, CT.

Saperstein, M. \& Marcus, J.R., 2015, The Jews in Christian Europe: A Source Book, pp. 315-1791, Hebrew Union College Press and University of Pittsburgh Press, Cincinnati, $\mathrm{OH}$.

Shapira, N., 1960, 'R. Abraham Portaleone - The Physician, Encyclopedist and his Book Shiltei ha-Giborim (1542-1612)', ha-Rofe ha-Ivri 33(1-2), 109-116.

Schleiner, W., 1994, 'The contribution of exiled Portuguese Jews in renaissance medical ethics', in R. Waddington \& A.H. Williamson (eds.), The expulsion of the Jews: 1492 and After, pp. 147-150, Garland, New York and London.

Schleiner, W., 1995, Medical ethics in the renaissance, Georgetown University Press, Washington, D.C.

Scholem, G., 1957, Shabbetai Zvi and the Shabbetaic Movement in his Period, Am Oved, Tel Aviv [Heb].

Shilat, I., 1987-1988, The letters of maimonides, Ma'aliyot, Jerusalem.

Smith, C.M., 2005, 'Origin and uses of primum non nocere - above all, do no harm!', Journal of Clinical Pharmacology 45(4), 371-377. https://doi.org/10.1177/ 0091270004273680

Steinberg, A., 1979, 'Prayers and oaths of patients and doctors', Sefer Assia 1, 248-256.

Steinberg, A., 1998, Encyclopedia of Jewish medical ethics, vol. 6, The Dr. Falk Schlesinger Institute for Medical-Halachic Research, Jerusalem [Heb]

Tamar, D., 1981, Researches in the Jews' History in Eretz Israel and in Eastern Lands, Mossad Harav Kook, Jerusalem, pp. 143-144 [Heb].

Varella, E.A., 2006, 'The oath of Amatus Lusitanus and the town of Salonique', Vesalius $12(2), 101-105$. 